\title{
Lenses and Experiences of Grade 10 English Teachers on Distance Learning Modalities: A Phenomenological Study
}

\author{
Fraulo Fer Marcelo', Juana Juanillas², Alberto Yazon², Karen Manaig², John Tesoro² \\ ${ }^{1}$ Aplaya National High School, Philippines \\ ${ }^{2}$ Laguna State Polytechnic University - Los Banos Campus, Philippines
}

\begin{abstract}
The qualitative existential-phenomenological study aimed to determine, describe, and investigate the perspective and experiences of the English Teachers on the implementation of distance learning modality using appreciative inquiry (AI) as its organizing principle. The participants were Grade 10 English teachers and selected students from public high schools in the Division of Santa Rosa City, Laguna, Philippines. Specifically, it addressed two central objectives: determine the best and most positive perspective and experiences of the English teachers in the implementation of distance learning modalities and determine the futuristic views of the English teachers on distance learning modalities for its successful implementation. As to the best and most positive lenses and experiences of the English teachers of Grade 10 English teachers on distance learning modalities, there were 20 themes generated. Likewise, as to the futuristic views of the English teachers on distance learning modalities for its successful implementation, 19 themes were developed. Based on the results, several factors that contribute to the development of the positive value system were identified through phenomenological analysis, including personal-related factors, peer-related factors, administration-related factors, stakeholders-related factors, and resources-related factors.
\end{abstract}

Keywords: appreciative inquiry, distance learning, English teachers, qualitative-existential phenomenological, lenses, perspective, experiences

\section{INTRODUCTION}

Most nations across the world have temporarily shuttered educational institutions to control the virus's spread and minimize infection for more than a year during the COVID-19 pandemic. Because of the rapid paradigm shift in the pedagogical environment, the education sector has been the most exposed to the pandemic's negative impacts, affecting over 1.2 billion learners globally. In the Philippines, more than 28 million students were affected. (UNESCO, 2020). Therefore, to address the problem, the necessity to shift to a new normal education was considered as the only viable choice, paving the way for the acceptance of distance learning (Tria, 2020).

Distant learning, also known as e-learning, online learning, and distance education, is not a new concept in the educational world. It has been used as an optional education delivery for the students who want to pursue studies despite their limited time, geographical location, or other personal circumstances that hinder them from participating in face-to-face classes. In the Philippines, e-learning became popular in early 2000 in parallel with the advent of ICT in government and education (Galeon et al., 2019). It was the UP Open University that pioneered online teaching and learning and offered research-based degree programs and open high schools.

Nowadays, distance education has become more prevalent in the public school system as it considers as the most appropriate, most applicable, and safest option to still pursue schooling in these times of pandemics still. In the Philippines, academic leaders proposed a responsive plan that could help Filipino students, teachers, parents, and administrators deal with educational problems in the new normal. To ensure 
International Journal of Theory and Application in Elementary and Secondary School Education (IJTAESE), Vol. 3 (2), 140-155 Lenses and Experiences of Grade 10 English Teachers on Distance Learning Modalities: A Phenomenological Study Fraulo Fer Marcelo, Juana Juanillas, Alberto Yazon, Karen Manaig, John Tesoro

that learners have the best learning opportunities, the Department of Education (DepEd) designed the Basic Education Learning Continuity Plan (BE-LCP) through the use of various learning modalities, which went into force in the school year 2020-2021. Essentially, the DepEd, through its Regional and Schools Division Offices, has undertaken the urgent and necessary development, production, and provision of learning resources, by its mandate, stated in the 1987 Constitution in Article XIV, sections 1 and 2 (DepEd Order No.18, s.2020).

Consequently, the government, through DepEd must rethink the very nature of distance learning to embrace, concerning the technologies needed in the teaching-learning process and the learning modalities such as Online Distance Learning (ODL), Modular Distance Learning (MDL), and TV/Radio-Based Instruction. As a result of this phenomenon, the government will need to develop and execute specific regulations to assist a new breed of educators. This is to guarantee that education stays inclusive and accessible to all people and that distant learning is not just limited online. This is because distance learning may be challenging to some students. According to Eye (2021), "the biggest challenge for online learning modality is dealing with technology." She pointed out that students can still struggle with accessing the technology even if they have the dedication and adaptation to online learning." According to reports, 45 percent of the Filipino population (46 million) and 74\% $(34,500)$ of public schools in the Philippines do not have access to the internet or learning gadgets (Jones, 2019).

Despite the disadvantages outlined above, distance learning may give a great chance for students to complete a lot of their learning at home. Pienta (2016) saw the advantages of flipped learning or pre-class activities like watching brief, pre-recorded lecture films to reinforce themes and encourage student-centered learning. According to Lapitan et al., 2021, mixed online learning, as a technique to promote students' engagement in their own learning process, is the most practical approach to adapt to the new normal since it combines the benefits of synchronous and asynchronous strategies. Teachers had to change their lesson plans, teaching techniques, and assessment methods to help learners adjust to the new normal because of the rapid switch to this learning mode.

\section{Novelty of The Study}

The researchers believe that integrating distance learning into teaching the English language begets valuable results, which may be pivotal for curriculum planning and implementation. With this in mind, this study recounted the positive experiences of English teachers on distance learning modalities which were elaborated and explored using appreciative inquiry. Cooperider and Srivastva (1987) highlighted that appreciative inquiry brings out the life-generating essentials and potentials of organizational and social existence, which focuses only on the positive experiences. Delving into the positive enablers of distance learning education instead of constraints that hinder its progress, English teachers could help them develop a positive value system that performs a significant role in delivering quality education to students in these uncertain times.

Equally important are the perspectives of English teachers on distance learning modalities in the formulation of policies towards the effective implementation of distance learning in schools. Additionally, the results of this study will give further clarity to the in-depth ideas of teachers regarding distance learning. Unlike other pandemic-related studies that have been written by various education scholars, the present study only looks at the positive experiences and visions regarding the implementation of distance learning education. It is hoped that through positive and appreciative perspectives and experiences, all school internal and external stakeholders would eventually embrace the new normal education and work together for its successful implementation to ensure that everyone is still entitled to have access to quality and inclusive education.

\section{RESEARCH METHOD Participants}

The English teachers were selected using purposive criterion sampling. Following the suggestions of Creswell (2018), the researchers chose English teachers who utilized distance learning modalities, whether modular or online modes of teaching. As for the students, on the other hand, they must be enrolled in the research locale and must use online or modular distance learning modalities.

\section{Research Instrument}


The researchers utilized an interview guide for the English teachers, which consists of 10 questions, to determine the best experiences obtained from distance education and to examine what needs to be improved in the delivery of language instruction through distance learning education.

\section{Data Gathering Procedures}

To collect the needed data, the researchers sought the approval of the Office of the Superintendent regarding the conduct of the study. The researchers also wrote a letter of request addressed to the Office of School Principal, asking permission to conduct semi-structured interviews with the English teachers and focus-group discussions with the selected students. To avoid any physical contact adhering to the health protocols as mandated by the Local Government of Santa Rosa with their approved permission, the researchers utilized Google Meet and other online platforms such as Google Forms and Facebook Messenger to pursue the interview. Before the interview proper, the researchers discussed to the participants the overall objective of the study the benefits they could obtain from the study. Participants were asked to sign an 'Informed Consent contract," which was made through google forms, making the whole interview procedure ethical and legal. They were also requested to sign the "Data Privacy form" as a sign of permission to disclose relevant information obtained from the interview in the write-up.

As for the students, the researcher sought permission from the parents. After the permission was obtained, the researcher explained to both students and their parents the overall objective of the study, including the benefits they could obtain from the study. They were asked to sign an 'Informed Consent Contract" and "Data Privacy Form" to make the whole procedure ethical and legal. Parental consent was also considered since most of the students were minors.

\section{Data Analysis Procedures}

Following a modified version of Moustakas`s (1994), as cited by Eddles-Hirsch (2015, the researchers researcher transcribed and analyzed the interviews.

\section{Phenomenological Analysis Framework}

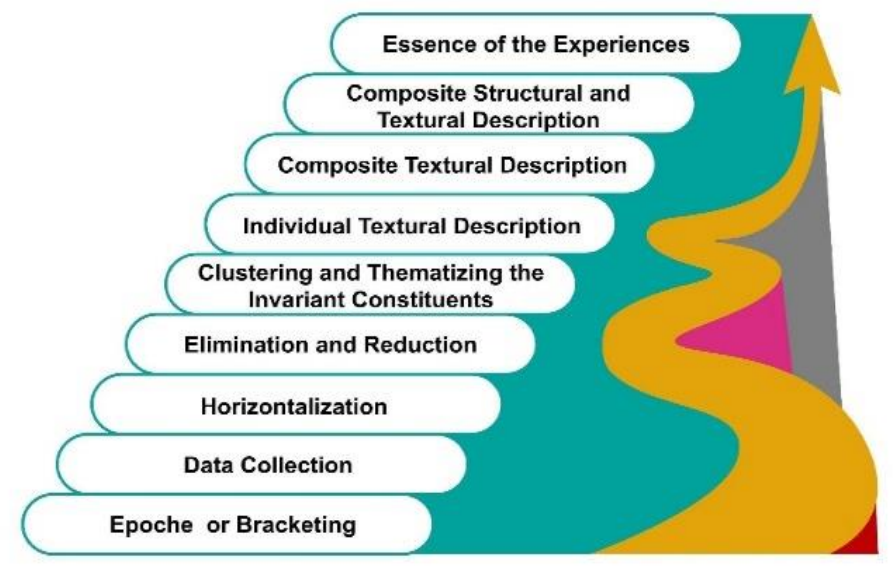

Figure 1. Phenomenological Framework

As shown in the framework, phenomenological reduction or horizonalizing was made where the researcher extracted statements from the interviews that are worth to be analyzed. These extracted statements are called horizons, which were later subjected to reduction to eliminate overlapping statements. After the invariant horizons had been identified, the researchers created core themes to describe these meaning units gathered from reduction analysis. These clustering and thematizing procedures were connected to the next step, which was writing textural descriptions for each of the participants. This was being carried out to present each of the individual participant's perceptions of the experience being investigated. The textural descriptions describe what the participants have experienced. Then, the researchers wrote the 
International Journal of Theory and Application in Elementary and Secondary School Education (IJTAESE), Vol. 3 (2), 140-155 Lenses and Experiences of Grade 10 English Teachers on Distance Learning Modalities: A Phenomenological Study Fraulo Fer Marcelo, Juana Juanillas, Alberto Yazon, Karen Manaig, John Tesoro

composite textural descriptions that enabled the individual descriptions of each participant to be represented as a whole.

After that, the researchers amalgamated the composite textural and structural descriptions and wrote a composite description that represents the life stories of participants. Lastly, to provide good descriptions of experiences, the researchers transformed these findings into educational language to highlight the essential structure of the phenomenon described by the participants in the composite description. This was also used to determine if the research questions had been achieved or not.

To validate the results, the researchers conducted focus-group discussions with the students to determine their positive experiences in distance education during this time of the pandemic. Supporting literature and studies were also provided during the discussion of results as a method.

\section{FINDINGS AND DISCUSSION Bracketing}

This process makes the results of the study authentic and reflective of the real experiences of the English teachers without possible manipulation and control on the part of the researcher.

During the conduct of the study, the researchers as much as possible disentangle themselves from the research process to maintain the integrity and validity of the research procedures. They also set aside preconceived experiences regarding distance learning education through avoidance of interrupting participants while speaking. Follow-up questions were asked minimally to avoid further disruptions during the sharing of life stories of English teachers. By being mindful of his limitations, the researchers were able to get in-depth information reflecting the positive experiences of the English teachers in new normal education.

To avoid personal judgment on the study results, they strictly followed the research protocols, particularly when dealing with humans as participants, to obtain the needed information in a most reflective and most natural way. They selected the participants based on their availability and who had utmost willingness to be part of the study to avoid personal bias of selection. A semi-structured interview with ten English teachers was conducted through Google Meet. During the interview, the researchers utilized audio and video recording of the interview to record the conversation with the consent of the participants. The researcher asked for the assistance of other people when transcribing the verbatim transcription of each participant to avoid possible manipulation of data reflecting their own understanding of the study.

\section{Horizonalization}

To discuss the horizonalization part of data analysis, the researchers presented significant statements taken from the responses of the participants during the scheduled in-depth interviews. They extrapolated a total of 200 significant statements from the interview results: 104 for the Discovery stage and 96 for the Dreaming stage. From the 104 significant statements in the Discovery stage, the researcher generated twenty (20) themes while nineteen (19) themes were formed out of the 96 significant statements for the Dreaming stage.

\section{Clustering and Generating Themes}

Clustering was done through surfacing the main idea of the following extrapolated significant statement from the interview results. To ensure that the core theme truly captured these statements, initial themes were first created. In reporting the results, these were further supported by related literature and studies. In that way, the results become more valid and reliable.

\section{Discovery Stage}

In this stage, the primary objective was to determine the best and most positive experiences the English teachers obtained from the implementation of distance learning modalities in the Division of Santa Rosa City, Laguna. The Discovery stage, according to Ludema et al., 2001, is aimed at identifying, emphasizing, and illuminating any variables that have contributed to 'the best in a particular circumstance. The Discovery stage also aims to determine positive capacity and appreciation. Below are the themes generated from the in-depth interviews with the English teachers. 


\section{Theme 1: Digitalization of Learning}

This theme describes the digitalization of learning as an obvious change in the new normal education. In this regard, participants jointly shared that technology utilization is one of the factors that put forward a major shift to making the present education system adaptive to the current demands and needs of the new normal set-up of the present education system. Through technology utilization that makes up the digitalization of learning, participants collaboratively mentioned that they were able to use different available platforms to make the distance learning modalities effective and adaptive with the new mode of learning. Such a new form of education has obliged the students to learn independently. In English language learning, participants argued that a stable internet connection and adequate learning resources also impact the success of the implementation.

\section{Theme 2: Self-Paced Learning Maximizes Authentic Development}

This shows the outcome that describes self-paced learning maximizes authentic development. Authentic development is achieved through the development of persons as human beings. The freedom of the people to realize their own potentials based on what they value is generated from the fact that they have absolute power to control their own subjectivities as learners. Based on the results, English teachers collaboratively mentioned that personal development is highly essential as inclination in the new normal setup in the educational system. Through self-discipline and different self-engagements, teachers emphasized that they were able to be prepared in expanding their knowledge, equipping their skills, and engaging themselves in participating in self-development seminars and teachings related to language learning provided by different stakeholders amidst pandemic situations.

\section{Theme 3: Need Assessment as an Essential Component}

This explains the needs assessment is an essential component of planning procedures. Needs assessment in language learning allows school administrators and teachers to determine what aspects they need to focus on and what sources and expertise are needed to cater to these identified aspects. Based on the results, English teachers explained that there are plans and projects put forward by the school to examine the students' language learning needs in the new normal setup. As mentioned by the participants, they were able to conduct the Learning Action Cell and Plans to assure that they properly address the language learning needs of the students in distance learning. They also provided learning support to assist students in learning language competencies even with little guidance from the teachers.

\section{Theme 4: Knowledge Sharing is a Real Driver}

This describes knowledge sharing as a real driver to adapt to the current situation. Despite the struggles that have obstructed them from delivering effective instruction, this was partly relieved through the knowledge-sharing practices in language learning displayed by students, teachers, and school administrators. Based on the results, English teachers jointly shared that the collaborative efforts and knowledge sharing with regard to effective language learning mechanisms made them gradually adjust to the new normal set-up of the present education system.

\section{Theme 5: Sustained Open Communication strengthens the Spirit of Cooperation}

This open communication allows coordinators, teachers, students, and parents to discuss and exchange ideas regarding issues and concerns and to be able to come up with preventive and reactive solutions to these matters. Based on the results, English teachers jointly shared that open communication is one of the important factors needed to keep sustained in dealing with the new normal set-up of the present education system.

\section{Theme 6: Stakeholders' Engagement as A Driver of Hope.}

It is true that the sustained dialogue and cooperation between the school and community could build a promising relationship that impacts the tenacity of the English teachers in responding to the newly created demands of language learning amidst pandemics. To concretize these results, English teachers jointly shared 
International Journal of Theory and Application in Elementary and Secondary School Education (IJTAESE), Vol. 3 (2), 140-155 Lenses and Experiences of Grade 10 English Teachers on Distance Learning Modalities: A Phenomenological Study Fraulo Fer Marcelo, Juana Juanillas, Alberto Yazon, Karen Manaig, John Tesoro

that stakeholders' support is very much essential to generate the human and physical resources required for pushing through language learning in distance education.

\section{Theme 7: Capacity Building for Distance Education}

Various seminars, training, and workshops in English language teaching through distance education have been conducted to train teachers to adapt to the distance education requirements. These were also conducted to provide teachers with necessary skills and adequate knowledge about language teaching and its salient features in distance education. In these regards, English teachers jointly shared that capacitybuilding strategies not only for teachers but also for all educational personnel and staff were perceived as a part of proactive preparations for the new normal set-up of the present education system.

\section{Theme 8: Acquisition of New Learning Experiences}

Although the pandemic situation has obviously paralyzed the educational system, the new normal education also provided English teachers new learning experiences, especially the sudden shift of delivery learning mode. In fact, English teachers emphasized that there are still new learning opportunities that have been brought by the pandemic, making them more optimistic in dealing with the changes. Distance education, which helps English teachers to connect with their students, has created an open and more relaxed kind of communication with regard to teaching English language education. It has also provided them new learning experiences as their skills in teaching English were mediated with the technological tools and applications. Furthermore, it was mentioned that teachers could attend webinars and teach students at the time due to the flexibility of distance learning.

\section{Theme 9: Strong Leadership is a Survival Asset}

Surviving from the adverse effects of a pandemic situation is no easy task to do. It needs collaboration, cooperation, competitive support, and of course, strong leadership. It is true that the leadership skills of both school heads and teachers are challenged in these uncertain times. They are urged to become steadfast and flexible in facing the challenges brought about by the new normal education. The critical aspect of managing schools amidst the pandemic relies on the proactive responses and strong vision of the school heads. In these regards, English teachers emphasized that the school heads proactively dealt with the changes by making school plans and programs responsive to goals of distance education with equal emphasis on essential skills such as reading skills in English. They also conducted meetings to update teachers regarding the status of distance education at the school level with a specific focus on English learning areas.

\section{Theme 10: Creativity at Its Finest}

The provision of distance learning has obliged teachers to harness their creative thinking as they were challenged to create engaging activities that would motivate students to enjoy learning despite the current situation. Creativity is activated as the teachers explore new strategies, use technological devices, and make language learning fun and engaging with the end view of teaching the students specific language competencies. Based on the results, English teachers shared that the pandemic urged them to boost their creativity in teaching English. They were able to make some activities for the students to enjoy the language learning process supported with instructional media such as videos and online activities as a new model of the teaching-learning process.

\section{Theme 11: Value of Goal Orientation}

Setting goals is viewed as the most important of planning activities. Goals determine the expectations of the society to the learners, which impact the selection process of learning content. Goals also provide direction as to how the learning process must be conducted and what types of lessons must be included. Such a goal-setting process is normally influenced by teachers' philosophical inquiry of education and assumptions about society. Furthermore, it is true that successful learning goals are those that are sensitive to current societal expectations and requirements. 


\section{Theme 12: Secured Health and Safe Environment}

Health is being considered as the main priority in these challenging times. To safeguard both teachers and students from contracting the COVID-19 virus, a transition from traditional face-to-face classrooms to distance learning was implemented. Based on the results, English teachers jointly shared that comfortability and health safety are highly valued in the new normal. They mentioned that working from home lessens the possibility of getting the unseen virus and allows them to safeguard their families. Moreover, for the comfortability and health safety, English teachers mentioned that they were able to ensure their health security in their most comfortable environment, their home.

\section{Theme 13: Improvisation Innovation of Learning Process}

Innovation has been at its peak when teachers were required to overhaul their methods of teaching by making those digitized to cater to the demands of distance instruction. Most English teachers have improvised learning activities and resources to continue English language teaching to the students. They shared that innovative learning is essential in the new normal set-up as it allows them to come up with an effective language instructional strategy that could serve as a resort in achieving the formulated English learning objectives. Furthermore, in innovative learning, they mentioned that they became more independent, innovative, and responsible in teaching English communication skills through the utilization of different online applications. More so, seminars and workshops regarding language learning in distance education were also positive enablers that helped them harness their inventing skills and creativity in English language teaching.

\section{Theme 14: Time Management is an Individual Responsibility}

Since attending schooling physically was not an option in the present academic year, the absolute power to manage the time has cascaded down to individual responsibility. Both teachers and students, who work independently in distance learning education, are given the freedom to manage their own time to attend to the requirements of academic undertaking. In fact, English teachers shared that they advised the students to be good stewards in using their time since no one would restrict them from following a specific schedule. They said that time management helps them to accomplish things on time. This lets them attend school duties, do household chores, and regain energy through rest.

\section{Theme 15: Provisions of Essential Skills}

The drastic changes brought about by the pandemic situation have altered the acquisition of learning competencies. Such a process has become more problematic and more challenging, especially if the students do not master the macro skills such as reading, writing, speaking, listening, and viewing in English. These essential skills command the degree of independent language learning that can be seen among students. Based on the results, English teachers mentioned that they encourage their students to keep the same enthusiasm in language learning, just like what they had shown during traditional face-to-face classes. They also reminded the students to hone their macro skills independently so that they could work on the assigned tasks with the little guidance of the teachers.

\section{Theme 16: Consistent Monitoring leads to Sustained Improvement}

Determining the progress of distance learning education allows them to become proactive in responding to the possible problems that may arise. Through consistent monitoring, teachers can give immediate feedback on the performance of the students, which in a way, can reduce the severity of the problem in the long run. In this regard, three English teachers collaboratively shared that giving feedback is one of the effective ways to align the students' attention on the language learning objectives despite the difficulty of achieving effective instruction through distance learning. They added that students are free to ask queries about the lessons for them to better understand the ideas presented to them, whether through online or modular instruction in English. 
International Journal of Theory and Application in Elementary and Secondary School Education (IJTAESE), Vol. 3 (2), 140-155 Lenses and Experiences of Grade 10 English Teachers on Distance Learning Modalities: A Phenomenological Study Fraulo Fer Marcelo, Juana Juanillas, Alberto Yazon, Karen Manaig, John Tesoro

\section{Theme 17: Adaptability as a Future-Ready Skill.}

Based on the interview results, participants jointly shared that being adaptive to the current situations made them gradually adjust to the new normal set-up of the present education system. Through adaptive mechanisms, participants mentioned that they were able to feel comfortable and flexible to adjust to the demands of the new normal situation. Indeed, as the participants disclosed, adaptability is a future-ready skill that helps them become proactive in dealing with the challenges brought about by new modes of the teaching-learning process.

\section{Theme 18: Significance of Integrative Learning}

Integrative learning allows students to relate various concepts together to strengthen the ideas learned from the process. The ability of integrative skills and competencies strengthens language learning since these are being applied to real-life situations. Three English teachers collaboratively mentioned that the integration of skills and values makes them steadfast in dealing with the current requirements of the new normal education. They also argued that every skill, knowledge, and competency in English being acquired by the students could be integrated into English language learning since language is everywhere.

\section{Theme 19: Self-Initiated Learning for Development}

Self-development is one of the positive effects being realized during these uncertain times. The training and development initiatives performed by various agencies and organizations made them fully equipped with the relevant knowledge, skills, and attitude in teaching English. As revealed in the table, English teachers shared that initiatives, support, and assistance from DepEd made them well-prepared and equipped with skills needed to deliver English language teaching through distance learning education effectively.

\section{Theme 20: Describing the Technical Assistance as a Human Capital.}

As previously discussed, collaboration and knowledge sharing are essential to adapt to drastic changes. The formation of a technical working group would be tasked to address all issues regarding distance learning that truly helped them in making distance education effective. This created technical working group is required to put forward assistance to those teachers and students who can hardly deal with the new normal education. Two English instructors agreed that technical help is critical in the new normal set-up because it relieves teachers of the stress of implementing distant learning in order to achieve a learning continuity plan in English.

\section{Dreaming Stage}

This stage explains the futuristic views of the participants on distance learning modalities. Stevenson, 2019, mentioned that the focus of the Dreaming Stage is to think about possibilities beyond the realm of present-day thinking. The following themes below were generated from the semi-structured interviews with English teachers as they revealed their wishes, aspirations, and inclination to improve the implementation of distance learning education.

\section{Theme 21: Cooperation as an Enabler of Productivity}

Productivity is measured on how efficient and effective the outcomes and efforts are after the aggregated resources have been invested in. The cooperation among school stakeholders is a contributor to achieving educational productivity despite the uncertainty of the situation and disruptions of traditional faceto-face classes. Based on the results, English teachers cited several situations in which cooperation seems a valuable element in the success of distance learning education. Consequently, they wished for sustained cooperation among stakeholders that helps guarantee productivity and achievement in language learning.

\section{Theme 22: Internet Connection as a Public Good}

Unlike before, internet connection nowadays has become a national need of both teachers and students who are choosing online education. Stable internet connection permits both individuals to still continue effective instruction despite not having the classes through a traditional face-to-face setting. Therefore, internet connection at a high-speed level is demanded by almost all students as it is the only way 
for them to connect and communicate with their teachers while at home amidst uncertain times. In this regard, English teachers wanted learners to have free access to the internet connection to make language learning more interactive and engaging in language learning despite the current educational setting. They collectively wished for internet allowance and other needed resources to make English teaching and to learn in distance education possible and successful.

\section{Theme 23: Collaboration as a Driver of Change}

Collaboration and knowledge-sharing are two essential elements that must be consistently in place whenever new programs or new practices have been introduced to the existing learning system. The current distance learning education, which is the DepEd's initial response to the new normal setting, needs to be executed collaboratively to ensure that every student could gain equal opportunities to quality education amidst the pandemic situation. In these regards, English teachers conveyed their wish to uphold camaraderie among colleagues through sharing of good practices, relevant ideas, and classroom programs that would positively impact the delivery of English language education in distance learning education. Moreover, they also desired to develop the principle of "oneness," which is crucial in facing the realities and challenges brought about by pandemic effects.

\section{Theme 24: Timeliness of Learning Assistance secures Readiness}

Preparation and readiness are essential to provide learning advancement to students amidst uncertain times. These two components command the execution of other related tasks in distance learning education. Moreover, the success of learning outcomes depends on the readiness of resources, including physical, human, mental, and material. Based on the results, English teachers wished that MELC and modules must be released in advance so that they would have enough time to review its content and prepare well for the lessons. Through the promptness in posting the modules, they would become more ready to cater to students' language learning needs since they have nothing to worry about the learning resources. In that sense, it would guarantee both teachers and students to keep pace with the demands of new normal education.

\section{Theme 25: Self-Discipline as a Key to Success}

Self-discipline is considered an important factor in accomplishing the assigned tasks on time. Since students work independently at their pace and choice, they must know how to manage their time properly, particularly in juggling various academic works, mental overloads due to too many activities, household chores, and other significant commitments. In this regard, English teachers wished that students consider the situation as an opportunity to cultivate themselves and embrace the value of independent language learning. They also wanted to see students become intrinsically motivated in language learning and be able to accomplish the tasks assigned to them confidently.

\section{Theme 26: Improvisation Innovation}

In times of pandemics, teachers learn to make improvised learning materials to cater to distance learning education. They attend webinars to equip themselves with adequate knowledge regarding innovative strategies that may set the ambiance and tone for effective distance learning education. In fact, English teachers wished that they would become skillful in navigating online applications that would possibly make language learning fun and engaging. They also aspired for schools to conduct necessary programs involving innovative teaching strategies as these would make them grow professionally and learn techniques that would allow students to learn English easily while having fun.

\section{Theme 27: Competent Macro Skills}

Since students learn independently in distance education, it is strictly important for the students to have competent speaking, reading, viewing, listening, and writing skills because these would make them survive in new normal education. In that sense, teachers still provide activities and monitor the progress of students in honing their basic skills in the English language despite not being physically present in the classroom. Based on the results, English teachers consistently monitored their students' acquisition of macro 
International Journal of Theory and Application in Elementary and Secondary School Education (IJTAESE), Vol. 3 (2), 140-155 Lenses and Experiences of Grade 10 English Teachers on Distance Learning Modalities: A Phenomenological Study Fraulo Fer Marcelo, Juana Juanillas, Alberto Yazon, Karen Manaig, John Tesoro

skills embedded in MELC, determined progress through formative assessment, and employed individualized mentoring.

\section{Theme 28: Acquisition of Future-Ready Skills and Opportunities}

The paralysis that was observed in the education system has inspired educational planners to inculcate future-ready skills into the learning goals and standards to reduce the possible vulnerability to shocks. Essentially, future-ready skills make teachers and students flexible to whatever unexpected distractions and disruptions that might obstruct the execution of educational plans. Based on the results, English teachers jointly wished to acquire opportunities and experiences that would eventually benefit their students. They also wanted to acquire new opportunities for their own development and survival and to impart new experiences to students which they could apply for future transactions in the ever-changing world competent involving English communication skills.

\section{Theme 29: Consistency directs Academic Success}

The consistent implementation of the program makes both teachers and students focus on the learning goals. Teachers become more strategic and scientific as they figure out the best way to achieve academic success amidst the pandemic. Consistency makes them track their progress, determine their strengths, and identify their weaknesses in language learning which are all critical contributors to high academic achievement in English. In this regard, English teachers wish that they continue to utilize assessment tools and procedures and implement programs that positively impact students' wellbeing. They also desired to have constant communication with students to keep their interest and confidence in learning.

\section{Theme 30: Provision of Healthy and Secured Teaching Environment}

Health security is the primary objective of distance learning education in the present academic year. The shift from the traditional way of educating students to a more advanced and technologically mediated education conforms to the health and safety protocols promulgated by the national government to protect both teachers and students from acquiring the virus. Such type of education seems to be the mostappropriate and safest educational delivery to be utilized in these uncertain and extraordinary times. From these perspectives, English teachers wished to venture into this modality to avoid themselves from being infected by the unseen parasites. They also wished to have more protective equipment and materials which they could use when going to the school for triple security aside from social distancing and the use of alcohol. However, although distance education seemed to be the most feasible in the current context, English teachers also wished that DepEd consider their mental and social well-being since too much exposure to online classes and regimented tasks created by modular instruction might also be dredging on their part as teachers.

\section{Theme 31: Development is an Aggregated Vision}

It is the outcome when the school stakeholders work together to achieve collective operating goals. While it is argued that stakeholders may have various visions on educational processes and outcomes, they must still have collective organizational goals that make them act in a cohesive manner. Based on the results, English teachers aspired to experience a comprehensive training/workshop about new strategies in teaching English suitable for distance learning. Having such helps them to come up with fun and engaging activities in language skills that affect the achievement of quality education. Also, such training development would assist them in designing skills-based modules relevant to English language learning.

\section{Theme 32: Creation of Flexible Learning Support Program}

Learning supports are much needed in these times of new normal education as not all students and teachers have the ability to adapt to the system quickly. These learning supports must be consistently and collaboratively provided to them to ensure sustainability and gradual adaptation to the situation. Based on the results, English teachers wanted to propose programs that would further assist students in their language learning needs. They also wished to inculcate the value of flexibility, compassion, and resourcefulness, which are essential attributes to still continue looking at situations from positive perspectives. 


\section{Theme 33: Utilization of Innovative Teaching Strategies}

Innovation seems to be ubiquitous nowadays as it paves the way for teachers to keep pace with the current demands of new normal education. They are obliged to innovate their teaching strategies, assessment tools, and learning environment making those updated, relevant, and appropriate to distance learning education. Based on the results, English teachers wanted to pursue innovative language teaching practices through integrating new strategies and localized learning resources into the teaching-learning process. They also utilized suggested innovative learning programs that help them sharpen learners' basic literacy skills in English.

\section{Theme 34: Reading Skill as an Adaptive Mechanism.}

The ability to read with comprehension helps a lot to achieve success in distance learning education as students could execute the tasks independently and effectively by just following instructions presented in the materials. This is the reason why, as English teachers desire, reading programs should be intensified, knowing the fact that some students have struggled in surviving in distance education programs due to poor reading ability with comprehension. They usually used reading applications and practices for the students to execute, affecting the individual and school success.

\section{Theme 35: Utmost Consideration keeps Positive Wellbeing}

The sudden shift to distance learning education has instigated shocks to almost all teachers and students, whether in public or private schools. They face recurrences of teaching-learning difficulties as both of them are mostly novices in the new normal setting. Based on the results, English teachers wished that utmost consideration must be given to them when dealing with regimented and complicated tasks created by the pandemic situation. They also wished that compassion and empathy should be unselfishly provided to them to continue to have positive wellbeing. Not only teachers but also students who have encountered adjustment difficulties must be given consideration and compassion in the education parlance since this distance education may positively or negatively affect their wellbeing.

\section{Theme 36: Promptness leads to a better plan}

Timely submission of the academic requirements helps teachers in providing corrective feedback and in determining what is lacking among the students' competencies. It also allows them to forecast possible assistance that could be provided to struggling students who have difficulty in this new normal education. Based on the results, English teachers wished that students submit their accomplished modules before or on the specific given data or to provide them with immediate feedback towards continuous improvement. Moreover, they argued the promptness of the students when submitting academic requirements allows teachers to plan for the possible intervention, remediation, and assistance in English language learning that would help improve distance learning education.

\section{Theme 37: Communication as a Motivating Force}

Communication about personal struggles and matters makes students motivated as they know that they are not alone in the adjustment journey. Personal communication that primarily concerns building rapport with students has strengthened their positive outlook to still aspire for academic success. Based on the results, English teachers wished to have more time to communicate to each student personally not only for tracking their academic progress but also for cheering them up amidst the difficult situation. They wanted to entertain questions that do not significantly deal with the module-related queries but questions that delve into the wellbeing, struggles, and success they have experienced amidst pandemic situations.

\section{Theme 38: Strong Aspiration for Success}

Maintaining a positive outlook in the current situation may be difficult for teachers to do as they are bombarded with a lot of drastic changes besetting the educational system. Teachers' patience and flexibility were partly measured in this new setting. In this sense, English teachers desired to keep for themselves any possible opportunities that would help them deliver effective instruction to students. They also hoped that their experiences, persistence, and aspirations shown in surviving from these drastic changes would 
International Journal of Theory and Application in Elementary and Secondary School Education (IJTAESE), Vol. 3 (2), 140-155 Lenses and Experiences of Grade 10 English Teachers on Distance Learning Modalities: A Phenomenological Study Fraulo Fer Marcelo, Juana Juanillas, Alberto Yazon, Karen Manaig, John Tesoro

eventually inspire students, making them stay positive in dealing with new tracks and tricks in language learning.

\section{Theme 39: Strong School-Community Partnership}

School-community partnership is a promising affiliation that helps teachers and students to acquire resources needed for the resumption of classes. Such collaboration creates a positive impact not only on the school management but also on the clienteles' wellbeing as they become more motivated to continue schooling due to sustained learning provided by the community. In this regard, English teachers wished that a lot of school stakeholders from the community would help them in facilitating learning through donating resources in which the schools are lacking. True enough, the spirit of teamwork was best exemplified by sustained dialogue and sharing of resources between the school and community.

\section{Discussion}

Textural Description

The themes generated depicted the positive experiences and thoughts are considered to be valuable regarding the implementation of distance learning education. English teachers shared that these identified enablers gave life and enhanced positivity the distance education amidst the pandemic-induced problems.

As discussed above, English teachers collaboratively reported that technology utilization defined the major shift to making the present education system adaptive to the current demands and needs of the new normal set-up. This technology-mediated instruction obliged them to improve themselves through selfexploration and self-initiated development with regard to using online learning applications. They were able to engage in knowledge production and exchange about the application of technological innovation in the teaching-learning process, in addition to self-development. Such cooperative efforts helped them to survive in these perilous times, particularly in coping with the many demands of students in the middle of the epidemic. In support of these claims, Kennedy and Duffy (2017) discovered that the crucial component for successful remote education is a collaboration among key players who use the technology. They described the collaborative procedures they feel are necessary for a networked learning course.

Adjusting with the new normal education was no easy task at all since there were various considerations that needed to be considered. However, through the consistent support of the stakeholders, English teachers affirmed that coping with the new normal demands and appreciating distance learning education became much easier for them as there are groups that have shared resources and passion for educating young minds. This echoed the results of De Villa \& Manalo (2020), in which they argued that since the school cannot provide all needs of teachers due to its limited resources, the gaps are filled through continuous support through community engagement and partnership with stakeholders. As a proactive response to the COVID-19 Situation, the Department of Education (DepEd) has created Memorandum No. 53 s. 2020 or the Joint Implementing Guidelines on the 2020 Brigada Eskwela and Oplan Balik Eskwela; and the Adopt-A-School program under Republic Act No. 8525 to strengthen school-community partnerships to support Basic Education Learning Continuum (BE-LCP).

Aside from that, another learning support provided to them was capacity building, training, and development initiated by the DepEd office. They were encouraged to attend webinars and mini-workshops to equip themselves with adequate skills, competencies, attitudes, and knowledge regarding the appropriate execution of distance education, especially in English. Likewise, De Villa et al. (2020) also highlighted that the higher offices and school authorities might work with the teachers in addressing the challenges they face as they migrate to the new normal teaching practices. Necessary resources and relevant training should be provided among teachers to successfully deliver quality education.

More than stakeholders' assistance and capacity development, leadership also contributed to keeping English teachers on track, especially when administrators consistently uphold open communication, sharing of best practices, and consistent monitoring to determine the progress of distance education. Through the above-mentioned provisions and assistance, English teachers were able to exercise their creativity, innovative thinking, and health security.

Moreover, English teachers revealed that making students well-oriented about the learning goals positively contributes to academic success. They also confirmed the importance of time management and competent essential skills as contributors to making themselves future-ready. This becomes successful 
through the ability of the teachers in integrative teaching and the right amount of technical assistance provided to them.

As for the Discovery stage, there were identified positive elements and enablers that made distance learning education successful from the perspectives of teachers, at least. These elements that surfaced from the discussions truly play significant roles in instilling into the minds of the school administrators, English teachers, other teachers, parents, and students the value of cooperation, open-mindedness, and learning assistance to help adapt to the drastic changes that have paralyzed the whole education system.

Based on the aggregated results, English teachers wished for several elements needed to execute distance learning education properly. Since distance education occurs, whether modular or online, teachers wished to have a stable internet connection and promptness of submission of academic requirements so they could plan ahead of time since language learning at home is somewhat taken as a critical process. This is supported with the study of $\mathrm{Wu} \&$ Turner (2016), in which they mentioned that high-speed internet connectivity provided by broadband services have a significant impact on reducing the class time allocated by learners searching for information on the internet, and also provide learners with more chances of gaining for knowledge and making more online interactions possible.

It also emerged from the results that English teachers also desired to have constant communication with the students and parents to monitor their progress in distance learning and to become proficient in using online applications to produce innovative teaching strategies to achieve high students' academic success in language learning. This endeavor would not solely be realized with the support of the stakeholders, cooperation among colleagues, and strong community partnership which teachers also aspired for. Similarly, Kemp (2017) wrote an essay in which she said that community engagement with schools complements and supports the values, culture, and learning opportunities that schools can give for their kids. In other words, when teachers, employees, parents, businesses, nonprofits, service groups, and others collaborate, they can genuinely make a difference in students' lives.

Dealing with distance learning education to arrive at an effective language learning strategy could be difficult for some teachers; therefore, English teachers wished for utmost consideration to their well-being and consistent implementation of effective classroom practices in distance education delivery. They also wanted students to have competent basic skills so that they could learn independently and acquire language learning skills in a healthy and safe environment. his is in line with Pierce's (2020) assertion that independent learning is an important ability for kids to develop since it fosters creativity and intellectual curiosity. It also encourages students to concentrate on the overall learning process rather than just one skill at a time. Teachers are preparing students for future success as life-long learners outside of the classroom by teaching them how to think independently at this period of distant learning.

\section{Structural Descriptions}

This part generally states the context or setting that influenced how the English teachers experienced the phenomenon. Based on the analysis of the interview results, the positive thoughts, experiences, dreams, and aspirations of English teachers regarding the implementation of distance learning education were influenced by these factors: personal-related factors, peer-related factors, administration-related factors, stakeholders-related factors, and resource-related factors.

English language learning is truly challenging in these uncertain times, particularly with the face-toface assistance of the teachers. However, despite the difficulties encountered in learning the second language, there were several factors that worked together to make the implementation of distance learning education in English classes successful. The first set of identified factors is the personal-related factors which include innovative strategies, creativity, time management, and independent learning. English teachers mentioned that in pursuing language education amidst the pandemic, they need to come up with fun and engaging activities that would sustain the motivation of the students through face-to-face interaction was not done. The creativity side of the English teachers was further improved and cultivated as they have acquired new learning experiences due to the paradigm-shifting in language learning. These innovative strategies mustalso nurture and cultivate students' macro skills such as speaking, writing, reading, listening, and viewing, which play significant roles in English language learning. Aside from that, they also need to make students understand the value of independent learning and prompt submission of the academic requirements for 
International Journal of Theory and Application in Elementary and Secondary School Education (IJTAESE), Vol. 3 (2), 140-155 Lenses and Experiences of Grade 10 English Teachers on Distance Learning Modalities: A Phenomenological Study Fraulo Fer Marcelo, Juana Juanillas, Alberto Yazon, Karen Manaig, John Tesoro

providing immediate and corrective feedback. According to Daniel et al. (2016), while self-efficacy has been shown to have positive effects in face-to-face education, the antecedents and consequences of self-efficacy in online distance education are less clear. They observed that a positive student attitude and digital literacy have a significant influence on self-efficacy as a consequence of his research. As a result, peer engagement, learning management system (LMS) contact, and convener interaction all enhance as a result of self-efficacy.

The second set of identified factors is the peer-related factors which are composed of knowledge sharing, collaboration, needs assessment, and technical assistance. Although distance education was not new in educational parlance, this was somewhat novel in the public-school environment as teachers usually hold class through face-to-face interaction. Several adjustments have been initiated by both teachers and students to pursue schooling amidst this pandemic situation. In this regard, English teachers put high importance on sharing knowledge and best practices in handling distance learning. They also highlighted the technical assistance needed to ensure the successful implementation of distance learning education. These mechanisms have validated the urgency of collaboration and sustained assistance in meeting the demands of current situations. Moreover, English teachers wished that more of their colleagues would engage in needs assessment and monitoring and evaluation to keep themselves updated regarding the implementation of distance learning. This was supported by the statement of Okai-Ugbaje et al. (2020), in which they emphasized that collaboration is a key tool to create a meaningful learning experience for all. Therefore, if parents or guardians understand the needs of their children, it makes them more engaged in extending help and support, and in return, these encourage teachers to become more creative and dedicated in providing quality education among their learners.

Moreover, the third set of identified factors is the administration-related factors which include training and development, utmost considerations on teachers' wellbeing, and strong leadership. English teachers emphasized the response of DepEd in the new normal setting. The conduct of capacity building through webinars, weekly meetings, and in-service training made them well-equipped with the knowledge and skills on the relevant practices, procedures, and processes in distance learning education. They also noted that strong leadership had motivated them to do well in the distance learning delivery as school heads continuously checked on their progress and personal challenges, which truly added factors to creating a motivating and engaging environment. However, English teachers wished that utmost considerations for their wellbeing must be equally provided to them. In this regard, Mizell (2010) stated that the most significant variables in improving student success are teacher quality and school leadership. To be as effective as possible, teachers, school, and district leaders must continuously develop their knowledge and abilities in order to adopt the finest educational methods.

Then, the fourth set of identified factors are the stakeholders-related factors which include assistance and support, collaboration and engagement, and open communication with parents. It is a fact that learning resources needed to pursue distance learning were not enough considering the number of learners; therefore, the assistance and learning support provided by the stakeholders were really helpful in the current context. Stakeholders' engagement truly made significant mechanisms that enable language learning at home possible. However, English teachers wanted that parents must hold open communication with them as they need to track the learning progress and difficulties experienced by the students through sustained dialogue and feedback. Through that, English could initiate valuable programs and projects that assist students in adapting to changes.

Similar to what was stated in an article of Paine, 2019, he mentioned that schools exist to serve the educational needs of the community. He added that when schools are sharply focused on specific, missionoriented outcomes and when they are consistently successful in delivering on the mission, they are considered at their best. Likewise, the community is at its best when its stakeholders are aware of the school's performance and when they are collaboratively supporting their needs. Thus, the schools need to identify and actively encourage and engage stakeholders in fulfilling the mission and enacting the vision of all students in school.

Lastly, the fifth set of identified factors is the resources-related factors which include modules, digital tools, and internet connection. To deliver distance education effectively, there are three requirements that need to be met: a.) modules, b.) digital tools, and c.) internet connection. For online instruction, although they stated that LGU and other organizations helped in acquiring digital tools for both teachers and students, such as laptops and tablets, English teachers still wished for a stable internet connection for both students and 
teachers. An intermittent internet connection reduces the motivation and enthusiasm of both entities in learning. For modular instruction, English teachers wanted to deliver and retrieve learning modules on the specified date so that they could provide immediate feedback to students as they monitor and evaluate their learning progress. Incongruent with the study of Musingafi, 2015, he found out that there are several related challenges in distance learning, first was in terms of individual-related challenges, such as the lack of sufficient time for study and problems related to the access and use of ICT. While for related institutional challenges, it was found that delayed or lack of study materials is one factor to consider. Further to address these challenges, he recommended equipping students with independent study skills, regularly training students and teachers on how to work with ICT; and must ensure enough production and delivery of study materials.

\section{CONCLUSION}

The following issues and implications were drawn from the analysis of the textural and structural accounts of the participants:

English language learning is truly challenging in these uncertain times. However, despite the difficulties encountered in learning the second language, there were several factors that worked together to make the implementation of distance learning education in English classes somewhat successful. Looking at the positive experiences obtained from distance learning education allows teachers and students to develop a positive value system that would be applied to designing projects, training programs, lesson planning, activity planning, workshops, seminars, and various learning activities towards the attainment of educational goals. As mentioned, there are several enablers that contribute to the development of the positive value system. The first set of identified factors is the personal-related factors which include innovative strategies, creativity, time management, and independent learning; the second set of identified factors is the peer-related factors which are composed of knowledge sharing, collaboration, needs assessment, and technical assistance; the third set of identified factors is the administration-related factors which include training and development, utmost considerations on teachers' wellbeing, and strong leadership; the fourth set of identified factors is the stakeholders-related factors which include the assistance and support, collaboration and engagement, and open communication with parents; and the fifth set of identified factors is the resources-related factors which include modules, digital tools, and internet connection. To deliver distance education effectively, there are three requirements that need to be met: a.) modules, b.) digital tools, and c.) internet connection.

\section{REFERENCES}

Alea, A. et al. (2020), Teachers' Covid-19 Awareness, Distance Learning Education Experiences and Perceptions towards Institutional Readiness and Challenges.International Journal of Learning, Teaching and Educational Research Vol. 19,No. 6, pp. 127-144.

Aronson, Nancy A. (2010). A Study Of The Effects of Appreciative Inquiry on Teachers' Classroom Practice.

Arthur-Nyarko, E., Agyei, D.D. \& Armah, J.K. Digitizing distance learning materials: Measuring students' readiness and intended challenges. Educ Inf Technol 25,2987-3002 (2020). https://doi.org/10.1007/s10639-019-10060-y

Besser, A., Flett, G. L., \& Zeigler-Hill, V. (2020).

Adaptability to a sudden transition to online learning during the COVID-19 pandemic: Understanding the challenges for students. Scholarship of Teaching and Learning in Psychology.

Bhatty, Mansoor Ahmad (2020). Impact of Teaching Presence on Learning Outcomes: A Qualitative Study of Perceptions through the Lens of Online Teachers.

Biana, H. T., \& Joaquin, J. J. B. (2020). The ethics of scare: COVID-19 and the Philippines' fear appeals. Public health, 183, 2.

Beulah, J. (2020). Progress Monitoring Through The Lens of Distance Learning.

Brown. (2020). Advantages and disadvantages of distance learning. 
International Journal of Theory and Application in Elementary and Secondary School Education (IJTAESE), Vol. 3 (2), 140-155 Lenses and Experiences of Grade 10 English Teachers on Distance Learning Modalities: A Phenomenological Study Fraulo Fer Marcelo, Juana Juanillas, Alberto Yazon, Karen Manaig, John Tesoro

Buchanan, J. M. (2014). Public finance in democratic process: Fiscal institutions and individual choice. UNC Press Books.

Cooperrider, D. L., \& Srivastva, S. (1987). Appreciative inquiry in organizational life. In W. A. Pasmore \& R. W. Woodman (Eds.), Research in organizational change and development (Vol. 1, pp. 129-169). Greenwich, CT: JAI.

Cooperrider, D. L., \& Whitney, D. (2005). A positive revolution in change: Appreciative inquiry. In D. L.

Cooperrider, P. F. Sorensen Jr., T. F. Yaeger, \& D. Whitney (Eds.), Appreciative inquiry:An emerging direction for organizational development Champaign, IL: Stipes Publishing, pp. 5-9.

Kemp, Stella M. (2017). The importance of school, community partnerships. From the Daily Journal Archive.

Lapitan Jr, L. D., Tiangco, C. E., Sumalinog, D. A. G., Sabarillo, N. S., \& Diaz, J. M. (2021). An effective blended online teaching and learning strategy during the COVID-19 pandemic. Education for Chemical Engineers, 35, 116-131.

Mizell, H. (2010). Why Professional Development Matters. Learning Forward. 504 South Locust Street, Oxford, $\mathrm{OH} 45056$.

Ludema, J. D., \& Fry, R. E. (2008). The practice of appreciative inquiry. The SAGE handbook of action research: Participative inquiry and practice, 280-296.

Ludema, J. D., Cooperrider, D. L., \& Barrett, F. J. (2001). Appreciative inquiry: The power of the unconditional positive question. In P. Reason \& H. Bradbury (Eds.), Handbook of action research: Participative inquiry and practice. London: Sage,pp. 189-199.

Okai-Ugbaje, S. (2020). Towards a pedagogical and socio-technical framework for the strategic integration of mobile learning in higher education in low and middle income countries. Higher Education Research \& Development, 1-18.

Paine, Stan (2019). Engaging Students. Sustainability Series. v.6 Retrieved from https://www2.ed.gov/programs/readingfirst/support/stakeholderlores.pdf

Tria, J.Z. (2020). The COVID-19 Pandemic through the Lens of Education in the Philippines: The New Normal. International Journal of Pedagogical Development and Lifelong Learning, 1(1), ep2001. https://doi.org./10.30935/ijpdll/8311 